\title{
The role of oestrogen in the control of ciliated cells of the human endometrium
}

\author{
I. A. R. More and R. G. Masterton \\ Glasgow University, Department of Pathology, \\ Western Infirmary, Glasgow, G11 6NT, U.K.
}

\begin{abstract}
Summary. The incidence of ciliated cells in the human endometrium was determined. Conditions associated with an excess of oestrogenic activity were characterized by an increased incidence of ciliated cells, whilst oestrogen deficiency was associated with decreased numbers. When endometrium was cultured, addition of oestradiol-17 $\beta$ caused an increase in the ciliated cell population.
\end{abstract}

\section{Introduction}

Ciliated cells have been recognized in the human endometrium since the end of the last century (Benda, 1894). Originally believed to occur only in pathological conditions or as tubal metaplasia (Fruin \& Tighe, 1967), the ciliated cell has now been shown to occur in the normal endometrium (Fleming, Tweedale \& Roddick, 1968; Armstrong, More, McSeveney \& Chatfield, 1973) and to undergo cyclic changes in numbers, ranging up to a maximum of $20 \%$ in the ovulatory phase (Masterton, Armstrong \& More, 1975). Ciliated cells also occur in the genital tracts of other animals. Ciliation has been shown to be stimulated by oestrogen in ovariectomized immature monkeys (Allen, 1928), whilst complete loss of cilia in the rabbit oviduct follows castration (Flerko, 1951, 1954).

Such findings are suggestive of hormonal control over ciliated cell populations derived from paramesonephric tissues. This hypothesis was tested for human endometrial ciliated cells by examining pathological conditions in which hormonal upsets are known to occur. Experiments were also performed to demonstrate the action of oestradiol on the ciliated cells in organ culture.

\section{Materials and Methods}

\section{Endometrial tissue}

All tissues were obtained by diagnostic dilatation and curettage.

Normal. Seventeen specimens of post-menopausal endometria were obtained frem patients aged 43-76 years; 11 had presented with post-menopausal bleeding, 5 with uterine prolapse and 1 with a vaginal discharge.

Pathological. Forty-seven samples of hyperplastic endometria were examined. Thirty-seven specimens were obtained from women aged 20-52 years; 36 patients had presented with a variety of menstrual irregularities, one case of which was associated with a previous 2-year history of chlorotrianisene therapy, and the other was a patient with a uterine prolapse. Ten samples were obtained from post-menopausal women aged 48-68 years, all of whom had presented with histories of post-menopausal bleeding.

Specimens of chronic endometritis were obtained from 18 women aged between 18 and 51 years. In four cases the condition was associated with an intrauterine contraceptive device which had previously been removed. Of the remainder, one presented post partum and the rest had histories of menstrual irregularities.

Histology. The tissue was fixed in buffered $4 \%$ formaldehyde, embedded in paraffin wax, and 3-4 $\mu \mathrm{m}$ sections were stained with $1 \%$ toluidine blue for 2-3 min. Any samples showing gross tissue 
damage or insufficient material for statistical analysis were excluded from the survey. Sections were examined under oil immersion in a Leitz Orthomat microscope. At least 10 fields from each of two unselected blocks were photographed. From the prints a count was made of the numbers of epithelial and ciliated cells in the glandular structures and from these figures the $\%$ of ciliated cells was calculated. By this method at least 500 cells from the glandular epithelium were examined from each specimen.

\section{Culture experiments}

Samples were obtained by diagnostic curettage from 20 healthy menstruating women aged between 22 and 40 years. In each case the procedure was carried out during laparoscopic sterilization. The tissue was divided into three portions. One portion was fixed in buffered $4 \%$ formaldehyde ( $\mathrm{pH} \mathrm{7.4)} \mathrm{and} \mathrm{embedded} \mathrm{in} \mathrm{paraffin} \mathrm{wax,} \mathrm{and} \mathrm{5-6 \mu m} \mathrm{sections} \mathrm{were} \mathrm{stained} \mathrm{with} \mathrm{haematoxylin} \mathrm{and}$ eosin. After similar fixation and embedding, 3-4 $\mu \mathrm{m}$ sections of the second portion were stained with $1 \%$ toluidine blue for 2-3 min. Counts were made of the ciliated cell population as described above. The third portion of tissue was cultured.

All tissue manipulations were carried out in a laminar flow cupboard (Pathfinder, England) and aseptic methods were employed at all times.

To every $100 \mathrm{ml}$ medium 199 (Biocult Laboratories, Glasgow), 5000 i.u. penicillin (Burroughs Wellcome, London) and 10 i.u. insulin (Burroughs Wellcome, London) were added. The medium was gassed for $5 \mathrm{~min}$ with $95 \% \mathrm{O}_{2}: 5 \% \mathrm{CO}_{2}$ and $10 \mathrm{ml}$ fetal bovine serum (Biocult) were added to every $100 \mathrm{ml}$ modified medium. After incubation overnight at $37^{\circ} \mathrm{C}$ the $\mathrm{pH}$ was adjusted to $7 \cdot 4$ by addition of $1 \mathrm{~N}$-sodium hydroxide.

The tissue was cut into cubes with sides of $2 \mathrm{~mm}$ and placed on Millipore filters of $8 \mu \mathrm{m}$ pore size (Millipore S.A., France). The filters and tissue were then placed on stainless-steel grids cut to fit the central wells of Falcon organ culture dishes (Biocult). Sufficient medium was added to the central well to just touch the Millipore filter. In each of the experimental cultures the medium contained a known concentration of oestradiol-17ß (Sigma, London). Oestradiol ( $2 \mathrm{mg}$ ) was dissolved in $0.1 \mathrm{ml}$ ethanol and $10 \mathrm{ml}$ modified medium. Various quantities of this solution were added to 10 $\mathrm{ml}$ modified medium and this mixture used to fill the central well to give the different concentrations of hormone. Cultures with no added hormone were set up as controls. The culture dishes were placed in airtight plastic boxes, gassed with $95 \% \mathrm{O}_{2}: 5 \% \mathrm{CO}_{2}$ for $5 \mathrm{~min}$, sealed and incubated for various times. During the longer incubations the gassing was repeated at $24 \mathrm{hr}$ intervals. On completion of the incubation the tissue was processed as described for the pathological samples and the incidence of ciliated cells calculated.

\section{Results}

\section{Normal post-menopausal endometria}

On histological examination these specimens exhibited simple or cystic atrophy of the endometrial glands. Characteristically, the few narrow glands present were supported by a dense fibrous stroma of spindle cells and lined by an inactive low cuboidal epithelium. The initial values $(0-5 \%)$ for the ciliated cell frequency were consistent with normal pre- and post-menstrual levels (Masterton et al., 1975). Thereafter there was a steady decline until after 6 years the incidence approached zero.

\section{Endometrial hyperplasia}

Specimens from post-menopausal women showed normal atrophic endometrium with characteristic areas of cystic or adenomatous hyperplasia (see below). The hyperplastic areas were similar in appearance whether they had arisen during reproductive life or after the menopause; there was 
excessive proliferation of normal glandular and stromal elements. The glandular epithelium exhibited an increased mitotic activity and presented a pseudostratified appearance with occasional production of luminal tufts. The specimens were classified as being mildly, moderately or severely hyperplastic according to the degree of the above changes. In general, the appearance of the specimen could not be correlated with the interval from climacteric (Table 1).

Table 1. The incidence of ciliated cells in post-menopausal hyperplastic endometrial specimens at various times after the climacteric

\begin{tabular}{ccl}
\hline $\begin{array}{c}\text { No. of years } \\
\text { since menopause }\end{array}$ & $\begin{array}{c}\text { Ciliated cells } \\
(\%)\end{array}$ & Histological grading \\
\hline 1 & 34 & Moderate-severe \\
1 & 15 & Mild \\
1 & 19 & Moderate \\
2 & 20 & Moderate \\
3 & 10 & Moderate-severe \\
5 & 10 & Moderate-severe \\
5 & 6 & Moderate \\
10 & 24 & Moderate \\
15 & 12 & Severe \\
16 & 18 & Moderate \\
\hline
\end{tabular}

There was a marked increase in the numbers of ciliated cells compared with the very low postmenopausal levels of normal endometrium. No correlation was observed between the severity of the hyperplasia and the number of ciliated cells. Although the numbers of ciliated cells were variable, as a group they were not significantly different from the maximum numbers $(20 \%)$ in normal endometrial specimens $(t=1 \cdot 2856 ; P=0 \cdot 1009)$.

The $\%$ of ciliated cells in the hyperplastic endometria of patients of reproductive age was not related to the severity of the condition. The numbers rose during the proliferative phase as they do in a normal endometrium and reached a similar peak about 16 days after the last menses. Thereafter, the numbers remained high, although there was considerable individual variation, in contrast to the findings in normal post-ovulatory samples in which there was a steady reduction in the numbers of ciliated cells (Masterton et al., 1975). There was no significant difference between the hyperplastic values from Day 13 onwards and the maximum numbers of ciliated cells in normal endometrium $(t=3 \cdot 6797 ; P=0 \cdot 3272)$.

\section{Chronic endometritis}

The histology of these samples showed the presence of a stromal chronic inflammatory cell infiltrate composed largely of plasma cells, associated with an otherwise normal endometrium. The changes suggested an earlier stage with respect to the last menstruation than that given by the date of biopsy. The chronic endometritis was graded as either mild, moderate or severe but the severity had no apparent influence on the incidence of ciliated cells which varied cyclically with a peak around the middle of the cycle. At all stages, however, there was a significant reduction in the numbers of ciliated cells compared with those in the normal endometrium, e.g. the maximum incidence at mid-cycle was approximately $6 \%$ in endometritic endometria compared with $20 \%$.

\section{Culture experiments}

All the specimens were histologically normal at the time of curettage.

Tissue preservation, as determined by light and electron microscope examinations, was good up to $72 \mathrm{hr}$ in culture, but thereafter marked degeneration occurred with increasing length of culture. All observations were therefore limited to $72 \mathrm{hr}$. In control cultures at all stages of the cycle only 
a few precursor ciliated cells were found (Pl. 1, Fig. 1), but in tissues exposed to oestradiol-17ß there was a marked increase in the numbers of these clear non-ciliated cells (Pl. 1, Fig. 2). Occasional mitotic figures were seen.

For determination of the effects of oestradiol on the ciliated cell incidence in vitro, only cultures showing adequate tissue preservation were included. Fourteen 24- and 48-hr cultures and twelve 72-hr cultures were finally selected (Table 2 ), and the $\%$ of ciliated cells in the specimens before culture was compatible with the stated day of the cycle.

Table 2. The effects of different concentrations of oestradiol-17\% on the ciliated cells in normal specimens of human endometrium in culture

\begin{tabular}{|c|c|c|c|c|c|c|c|c|}
\hline \multirow{3}{*}{$\begin{array}{l}\text { Day of } \\
\text { menstrual } \\
\text { cycle on } \\
\text { which } \\
\text { specimen } \\
\text { obtained }\end{array}$} & \multirow{3}{*}{$\begin{array}{c}\text { Conc. } \\
\text { oestradiol- } \\
17 \beta \\
(\mu \mathrm{g} / 100 \mathrm{ml})\end{array}$} & \multirow{3}{*}{$\begin{array}{l}\text { Ciliated } \\
\text { cells before } \\
\text { culture }(\%)^{*}\end{array}$} & \multicolumn{6}{|c|}{ Absolute variation in $\%$ of ciliated cells $\dagger$} \\
\hline & & & \multicolumn{3}{|c|}{ Control cultures } & \multicolumn{3}{|c|}{ Cultures with oestradiol } \\
\hline & & & $24 \mathrm{hr}$ & $48 \mathrm{hr}$ & $72 \mathrm{hr}$ & $24 \mathrm{hr}$ & $48 \mathrm{hr}$ & $72 \mathrm{hr}$ \\
\hline 5 & 16 & 4 & -3 & 1 & 0 & 0 & 2 & 5 \\
\hline 8 & 4 & 8 & -1 & 2 & -2 & 8 & 5 & 8 \\
\hline 8 & 8 & 9 & 1 & -2 & 1 & 1 & -1 & 4 \\
\hline 11 & 0.6 & 10 & -3 & 2 & 0 & -3 & 5 & 3 \\
\hline 11 & 16 & 12 & 2 & -1 & 0 & 0 & 2 & 5 \\
\hline 13 & 8 & 19 & -3 & 1 & -2 & -2 & -1 & 3 \\
\hline 13 & 8 & 18 & 0 & -2 & 2 & 0 & -2 & -1 \\
\hline 14 & 10 & 23 & -4 & -3 & 0 & 0 & 3 & 3 \\
\hline 15 & 10 & 18 & -1 & 3 & - & 2 & 2 & - \\
\hline 16 & 6 & 18 & 2 & -2 & 1 & 5 & 6 & 3 \\
\hline 16 & 4 & 15 & -3 & 2 & 0 & -1 & 0 & 4 \\
\hline 17 & 16 & 16 & 1 & 1 & -4 & -2 & 3 & 2 \\
\hline 22 & 4 & 3 & -1 & 1 & 0 & 3 & 3 & 4 \\
\hline 26 & 16 & 1 & -0.5 & 1 & - & 0 & 1 & - \\
\hline
\end{tabular}

* Original \% ciliated cells in the uncultured part of each specimen.

$\uparrow$ Absolute variation in $\%$ ciliated cells $=(\%$ of ciliated cells in the respective culture $)-($ original $\%$ ciliated cells).

There were no significant differences between the numbers of ciliated cells in the original specimens and their respective control cultures; the mean ( \pm 2 S.E.) absolute variations being $0 \cdot 1 \pm 1 \%$ at $24 \mathrm{hr}, 0.5 \pm 1 \%$ at $48 \mathrm{hr}$ and $0.3 \pm 1 \%$ at $72 \mathrm{hr}$.

The majority of the oestradiol-treated cultures contained more ciliated cell precursors than did the control cultures. The differences between the two culture groups were significant at the $5 \%$ level in the 24- $(t=2.2109, P=0.0141)$ and 48- $(t=1.8518, P=0.0328) \mathrm{hr}$ specimens, in which the mean ( \pm 2 S.E.) increased numbers of ciliated cells were $0.9 \pm 1.5 \%$ and $2.0 \pm 1.2 \%$, respectively. The mean ( \pm 2 S.E.) absolute variation in the $\%$ of ciliated cells at $72 \mathrm{hr}$ was $+3.5 \pm 1 \cdot 2 \%(t=4.9343$, $\left.P=1.288 \times 10^{-6}\right)$. The concentration of oestradiol-17 $\beta$ used, or the stage of the menstrual cycle, did not appear to influence the response.

\section{Discussion}

Several authors have noted that endometrial hyperplasia is associated with increased numbers of ciliated cells (Maddi \& Papanicolaou, 1961; Fruin \& Tighe, 1967; Ferenczy \& Richart, 1974), but have not distinguished between post-menopausal hyperplasia and hyperplasia occurring during reproductive life, or followed the changes during the menstrual cycle. In our study, the $\%$ of ciliated cells in samples taken shortly after menstruation in women of reproductive age with hyperplastic endometria was similar to that in correspondingly dated specimens from the normal menstrual 


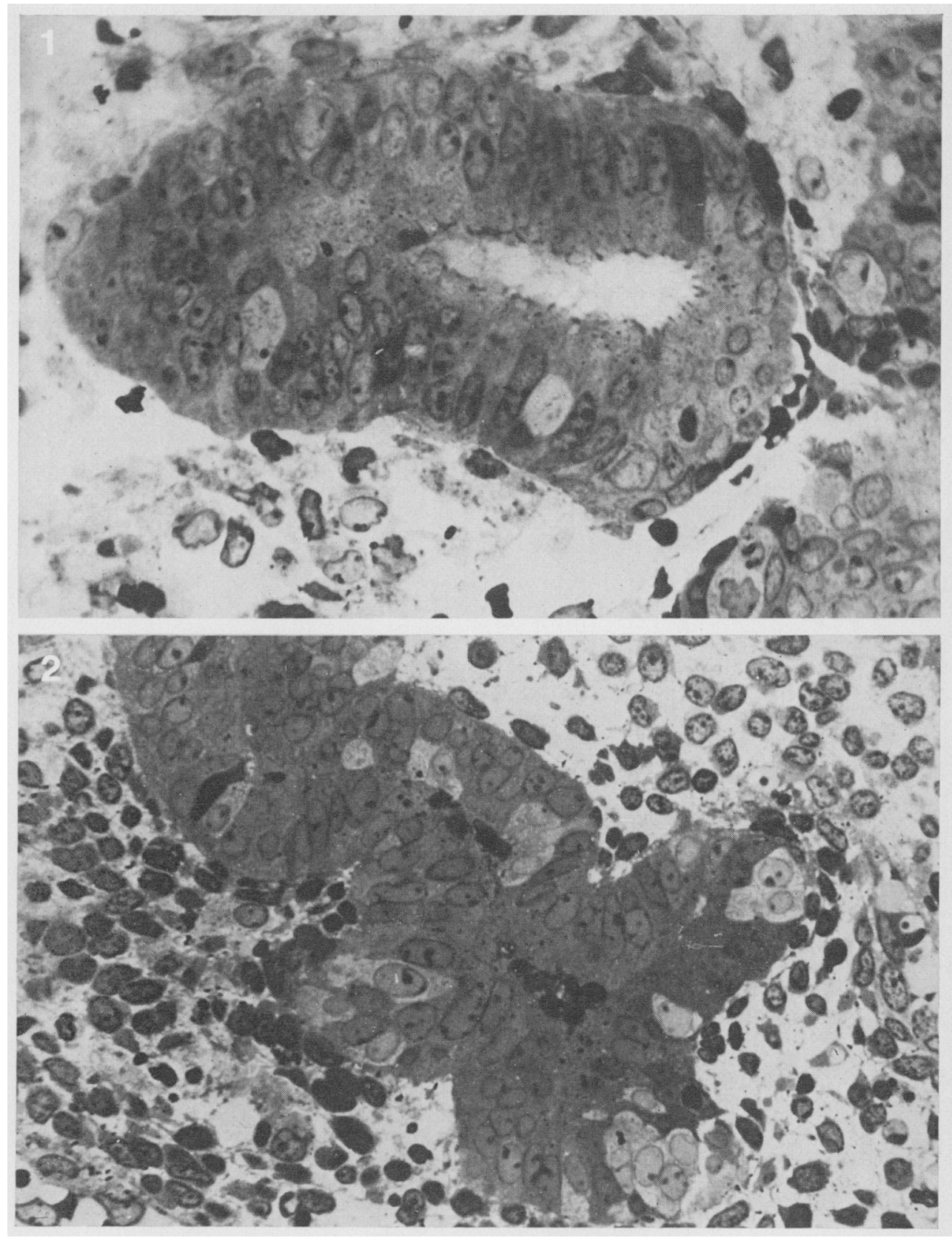

Sections of Day 8 specimens of human endometrium cultured for 72 hr. Toluidine blue, $\times 2000$. Fig. 1 . Control culture showing few clear cells. Fig. 2. Culture after treatment with $6 \mu \mathrm{g}$ oestradiol $/ \mathrm{ml}$ showing the clusters of clear cells adjacent to the basement membrane. 
cycle. This suggests that ciliated cell proliferation is a uniform process common to normal and hyperplastic cyclic endometria.

Maddi \& Papanicolaou (1961) considered that large numbers of ciliated cells were of diagnostic significance in cases of endometrial hyperplasia, but our findings suggest that this would be so only in the second half of the cycle when there are few ciliated cells in normal endometria. In post-menopausal endometria, however, the presence of ciliated cells is of significance at all times in the diagnosis of hyperplasia since normal post-menopausal endometria contain very few or no ciliated cells.

The gradual increase in the numbers of ciliated cells during the proliferative phase of the normal menstrual cycle (Masterton et al., 1975) suggests that, during this portion of the cycle, production of new ciliated cells predominates over their loss whilst the opposite is true of the second half of the cycle. The plateau region would therefore represent a stage of dynamic equilibrium where rate of production equalled the rate of loss. It is known that progesterone can antagonize the action of oestrogen in ciliated cell growth (Andrews, 1951) and this may explain the drop in numbers of ciliated cells during the second half of the cycle. In hyperplastic endometria the excess of oestrogen may therefore delay the antagonistic effect of progesterone and allow the continued production of ciliated cells so that the plateau is maintained. It has been suggested that ciliated cells are produced in the glandular endometria and that they can then move out to the luminal surface (Masterton et al., 1975). A corollary of the above continued production would therefore be a gradual build-up of ciliated cells on the luminal surface in hyperplastic states. Ferenczy \& Richart (1974) have demonstrated that the luminal surface of hyperplastic endometria attains a $91 \%$ incidence of ciliated cells.

The steady fall in ciliated cell numbers in post-menopausal endometria may mirror the gradual reduction in oestrogen levels following the climacteric. Similarly, a partial inhibition of the oestrogencontrolled proliferative phase by inflammatory processes may cause the reduced numbers of ciliated cells associated with chronic endometritis. If this explanation were expanded to include the glandular cell population it would account for the established histological finding that the appearance of such specimens is earlier than the stated date of biopsy in the menstrual cycle (Dallenbach-Hellweg, 1971). Other authors have described changes in ciliated cell population in pathological conditions; Scheuller (1968) noted that very few ciliated cells were present in atrophic endometria, whilst Fleming et al. (1968) found that ciliated cells were moderate or few in 8 of the 10 atrophic endometrial specimens which they examined. Ferenczy \& Richart (1974), in a scanning electron microscope study of the Fallopian tube, described a marked but focal loss of ciliated cells with severe and long-standing inflammatory conditions.

Studies of animals have produced conflicting reports and it is clear that there are marked species differences. Flerko $(1951,1954)$ described the complete loss of cilia from the rabbit oviduct following spaying whereas Dubuisson et al. (1972) reported that spayed rats showed no oviducal deciliation. Brenner (1965) contradicted the findings of Borell, Nilsson, Wersall \& Westman (1956) when he stated that oophorectomy of rhesus monkeys caused atrophy and deciliation of and loss of basal bodies from the oviducts, all of which he maintained could be reversed by oestrogen therapy.

Our organ culture experiments indicate that oestrogen caused an increase in the number of ciliated cells in human endometrium. The range of oestradiol concentrations employed $(0 \cdot 6-18 \mu \mathrm{g} / 100 \mathrm{ml})$ did not affect the response, and accords with the results of Bo, Krueger \& Garrison (1973) who showed that maximum uterine glycogen production in rats was independent of the dose of oestrogen used $(1-10 \mu \mathrm{g} / 100 \mathrm{ml})$. These findings suggest that the levels of oestradiol- $17 \beta$ being used are either at or above the saturation value of the oestrogen receptors. The ciliated cells stimulated by oestradiol appeared to be mainly the non-ciliated clear precursor cells situated at the basement membrane (Masterton et al., 1975; More \& Masterton, 1975), and mitotic figures were found in these areas. There was no increase in the numbers of mature ciliated cells. Since the normal maturation period for an endometrial cell is $48-72 \mathrm{hr}$ (Ferenczy \& Richart, 1974), the culture times achieved in our experiments were probably insufficient to allow significant numbers of ciliated cells to complete ciliogenesis. The increased numbers of ciliated-cell precursors with longer culture times appears to follow a direct mathematical progression and suggests that the induced rate of proliferation had a constant value. The 72 -hr culture results suggest that the increased rate of cell proliferation is independent of the stage of the menstrual cycle, and these findings may reflect the steady stimulation 
of an undifferentiated stem cell by oestradiol-17ß. This is consistent with the observed pattern of ciliated cell proliferation in normal and hyperplastic endometria.

The work was supported by an A.C.M.R. grant No. K/MRS/19/C183.

\section{References}

Allen, E. (1928) Further experiments with an ovarian hormone in the ovariectomised adult monkey, Macacus rhesus, especially in the degenerative phase of the experimental menstrual cycle. Am. J. Anat. 42, 467-487.

ANDREws, M. (1951) Epithelial changes in the puerperal Fallopian tube. Am. J. Obstet. Gynec. 62, 28-37.

Armstrong, E., More, I., McSeveney, D. \& ChatFIELD, W. (1973) Reappraisal of the ultrastructure of the human endometrial glandular cell. J. Obstet. Gynaec. Br. Commonw. 80, 448-460.

BENDA, C. (1894) Klenusches Handbuch der Han und Sexualorgane, p. 70. Leipzig.

Bo, W.J., Krueger, W.A. \& Garrison, B.M. (1973) Effect of repeated injections of oestrogen on uterine glycogen. $J$. Endocr. 59, 381-382.

Borell, U., Nilsson, O., Wersall, J. \& Westman, A. (1956) Electron microscope studies of the epithelium of the rabbit fallopian tube under different hormonal influences. Acta obstet. gynec. scand. 35, 36-41.

BrenNer, R. (1965) Renewal of oviduct cilia during the menstrual cycle of the rhesus monkey. Fert. Steril. 20, 599-611.

Dallenbach-Hellweg, C. (1971) Histopathology of the Endometrium, pp. 125-135. Springer, Berlin.

Dubuisson, L., Duluc, A.J., Bousquet, J. \& Zaray, M. (1972) Rôle des hormones ovariennes dans le processus de ciliation de l'oviducte de ratte. $C$. $r$. Séanc. Soc. Biol. 421, 574-577.
Ferenczy, A. \& Richart, R. (1974) Scanning electron microscopy of human female genital tract. $N . Y$. St. J. Med. 74, 794-802.

Fleming, S., Tweedale, D. \& Roddick, J. (1968) Ciliated endometrial cells. Am. J. Obstet. Gynec. 102, 186-191.

Flerko, B. (1951) Einfluss experimenteller Hypothalamus-Läsion auf das Eileiterepithel. Acta morph. hung. 1, 5-14.

Flerko, B. (1954) Die Epithelien des Eileiters und ihre Hormonalen Reaktionen. $Z$. mikrosk.-anat. Forsch. 61, 99-118.

FruiN, A.H. \& Tighe, J.R. (1967) Tubal metaplasia of the endometrium. J. Obstet. Gynaec. Br. Commonw. 74, 93-97.

Maddi, F. \& Papanicolaou, B. (1961) Diagnostic significance of ciliated cells in human endometrial tissue cultures. Am. J. Obstet. Gynec. 82, 99101.

Masterton, R., Armstrong, E. \& More, 1. (1975) The cyclical variation in the percentage of eiliated cells in the normal human endometrium. J. Reprod. Fert. 42, 537-540.

More, I.A.R. \& Masterton, R.G. (1975) The fine structure of the human endometrial ciliated cell. J. Reprod. Fert. 45, 343-348.

SCHeULLER, E. (1968) Ciliated epithelia of the human uterine mucosa. Obstet. Gynec., N.Y. 31, 215223.

Received 10 July 1975 